Journal of the Textile Institute Proceedings and Abstracts

\title{
LANCASHIRE SECTION: Meeting at Manchester, 11th February, 1919: Mr. T. FLETCHER ROBINSON in the Chair: THE ECONOMIC VALUE OF QUICK RAILWAY TRANSIT
}

\section{David Halliwell}

To cite this article: David Halliwell (1919) LANCASHIRE SECTION: Meeting at Manchester, 11th February, 1919: Mr. T. FLETCHER ROBINSON in the Chair: THE ECONOMIC VALUE OF QUICK RAILWAY TRANSIT, Journal of the Textile Institute Proceedings and Abstracts, 10:4, 70-75, DOI: 10.1080/00405001908630874

To link to this article: http://dx.doi.org/10.1080/00405001908630874

曲 Published online: 25 Nov 2008.

Submit your article to this journal $₫$

Џll Article views: 2

Q View related articles $\longleftarrow$ 
to end in securing such national control, and with sympathy and imagination operating in its administration, we ought to see a radical improvement in the road system. -R. C.

\section{THE COLOUR INDUSTRY.}

The recent appointment of Lord Moulton as Chairman-Designate of the British Dyestuffs Corporation gave additional interest to his attendance as the guest of the evening at the annual dinner of the Society of Dyers and Colourists, held at the Midland Hotel, Bradford, on March 21st. Lord Moulton responded to the toast of "The Colour Industry," and showed how the German dye factories on the Rhine had been devoted to the manufacture of enormous quantities of high explosives and poison-gas practically without alteration of their plant-a fitting exposure for the anniversary of the opening of the great German offensive exactly a year ago. Whilst deepening the conviction that the establishment of an adequate dye-producing industry is a national necessity of prime importance, Lord Moulton made the valuable point that this would not achieve its object unless there were dyers and dyeusers who would so employ the colours that their wares would also attain a pre-eminence in the markets of the world. In view of the increasing interest which the Dyers' Company is now taking in the dye industry. it was unfortunate that the Prime Warden (Mr. C. H. F. Christie) was unable to be present, but the Renter Warden (Dr. M. Onslow Forste, F.R.S.) was present, and proposed the toast of "The Perkin Medallist " in a graceful speech. The award of the Perkin Medal was made to Monsieur Raymond Vidnl (France) for his

\section{PROCEEDINGS OF}

\section{LANCASHIRE SECTION. Mecting at Manchester, 11th February, 1919. \\ Mr. T. Fletoher Robinson in the Chair. THE ECONOMIC VALUE OF QUICK RAILWAY TRANSIT.}

By Mr. David Halliwell.

THE future of the railway system is one of the many problems of reconstruction, and it is one of the most important, because the railway is a service which touches at some point or other practically every phase of human activity. It is becoming generally accepted that railways will never be handed back to private enterprise, but no official statement has yet been made, and in view of its importance the country has a right to know what is the policy of the Government, and whether it holds out any prospect of greater efficiency and public service.

The railway policy of the future should have regard for the general economic position of the country because its recovery from the devastation of war will depend, to a large extent, on the ability of railways to transport its products quickly. The discussion in the House of Lords some time ago in regard to the nation's finances was helpful in so far as it emphasised the importance of intensifying production and econo- pioneer work on sulphur black, and M. Vidal was accorded a rousing reception-not only for his technical achievements, but as a representrative of our gallant Allies. Mr. George Douglas, who was called upon to propose the toast of "The Colour Industry," in place of the Prime Warden of the Dyers' Company, found ready support from the company when he asked permission to amend the toast and substitute "The Allied Colour Industry." Mr. Charles F. Cross, F.R.S., was re-elected Chairman of the Society at the Annual Meeting immediately prior to the dinner. -M.

\section{OBITUARY.}

In last month's issue an obituary note recorded the removal of a member of the Council of the Institute by the death of Mr. W. Grierson, of Bolton. Record has now to be made of the demise of another member of the Council-Mr. Henry MeNiel, of Manchester. Mr. MeNiel had been in failing health for some months past, but it was not anticipated that any difficulty in recovery would be experienced. Unfavourable symptoms appeared, however, and the end was swiftly reached. The late Mr. MeNiel had experienced a long and varied career in public life. Above all things, he was an enthusiast in movements with which he became connected. $\mathrm{He}$ joined the Institute three or four years ago, and was instrumental in introducing many additions to the membership roll. A distinctive personality, with an optimistic outlook, Mr. McNiel was an interesting figure in the Institute movement, and his removal has caused many sincere expressions of regret on the part of Institute officers and members.

\section{THE INSTITUTE.}

mising capital in the future. The estimated indebtedness of 6,000 millions sterling, and a Peace Budget of 700 millions, represent a colossal burden to be faced with depleted man-power and capital resources. Whatever the idealists may say, we must come back to the fact that we are not going to live in an entirely new country in the future. Our inclustrial and commercial institutions will continue to be very much what they are to-day, because it is impracticable to move faster than the economic position of the period will permit. Increased production will almost certainly depend on the development of new ideas for intensifying the use of existing machinery. Lord Leverhulme, whose great practical ability is unquestioned, has put forward the suggestion that the principal means by which production may be increased is the use of machinery with the utmost continuity possible. This principle is specially applicable to a railway because its functions are continuous. Traffic is moving over the railways every minute from January lst to December 3lst. The aggregate mileage run by locomotives on the railways of the United Kingdom in 1913 works out at 1,294 miles per minute, which represents an average of 2,500 locomotives always at work. We have, therefore, to contemplate a mighty machine with a 
horse-power equal to 2,500 locomotives in constant movement. This machine is one of the principal links between the producer and consumer. Its function is to reduce the time which elapses in the transition of persons and commodities from place to place to an economic minimum.

The proposition I wish to submit for your consideration is that if we could raise the rate of movement, or increase the capacity of that huge machine, three things would be accomplished. It would (1) increase the efficiency of our depleted man-power; (2) economise our capital resources; (3) increase the productive capacity of the country. In order to attain this end, it will be necessary for the people who control the machine and the people who use it to work cooperatively.

Let us consider, first, the question of increasing the efficiency of our man-power by means of quick transit.

The commercial man's time is his capital, and the more time he can save in travelling from place to place the more time he has available for useful labour, not only to himself but to the nation. Slow and infrequent train services, particularly over long distances, mean a considerable waste of man-power time because the man is detached from business for unnecessarily long periods. There has been a good deal of chafing about the slow services between Manchester and London during the war. The North Western Company's fastest train between London and Manchester takes 65 minutes longer than the fastest pre-war express. Sixty-five minutes on the out and home journeys has made all the difference in an enormous number of cases to a commercial man anxious to make a journey to and from London in one day. In pre-war days, such a journey could be accomplished with comparative ease. The war services have meant a considerable waste of man-power both as regards the traveller himself and the hotel staff attending to his wants in London. This could not be avoided, because, in the national emergency, the Railway Executive Committee had to determine the matter on a balance of advantages and disadvantages. To offset the value of quick passenger train services there was (1) the necessity to reduce coal consumption : (2) the necessity to release as many men as possible for war service, which made it difficult to maintain the permanent way and rolling-stock up to the pre-war standard which enabled high speeds to be attained with safety. When normal conditions are restored, and assuming there is State administration, it will then be able to look into the question as to whether an augmented and an accelerated service, say, between London and Manchester, London and Liverpool, and London and Glasgow would not be to the national interest. There is no index of the social value of, say, four additional quick trains each way per day between these important cities. The additional cost of providing them would probably be about $£ 150,000$ a year. On the other hand, if each of the trains carried 200 people (i.e., 24 trains, 4,800 passengers), and one hour was saved to each passenger, that would represent a social gain of 4,800 hours per day, or $1,500,000$ per annum. It is a matter for speculation as to how far that saving would go to repair our depleted man-power resources. The problem is whether the value of $1,500,000$ hours of man-power time is greater than $£ 150,000$ required to avoid its loss. Quick railway transit for passengers has been given a definite money value in America. The New York Central and Penn. sylvania railways provides several quick express trains between New York and Chicago, and charge an extra fare amounting to one dollar per hour of time saved to the passenger. The standard time for an express train from New York to Chicago, 908 miles, is fxed at 28 hours. Trains scheduled to perform the journey in less than 28 hours are designated extra-fare trains, ancl the passengers are charged a supplementary fare calculated at the rate of one dollar for each hour less than the standard time for the journey, e.g., a twenty. hour train, being eight hours less than the standard time, carries a supplementary fare of eight dollars. The number of travellers willing to pay this extra fare of one dollar per hour is ample evidence that time means money to the commercial man. If in this country we estimated the value of each hour saved at 2s. 6d., the million and a half hours would be worth £188,000 per annum.

Now let us look at the question of quick transit from the point of view of the trader dispatching goods. Traders' capital is in one of two forms, either it is floating or it is solidified. Rapid transit brings the producer and consumer closer together and economises capital in two ways:-(1) By keeping money in circulation, or floating over the longest possible period; (2) manufacturers and tradesmen have not to provide warehouse accommodation for goods in stock. If transit is slow or unreliable, all sections in trade have to take that fact into consideration, and keep sufficient stock of raw material or manufactured articles on hand in order to run no risk of having their mills stopped or in anticipation of demand. All that means capital solidified and lying idle for a longer period than is absolutely necessary.

One of the witnesses appearing before the Light Railway Commissioners, a few years ago, in support of the application for a light railway in one of our Northern towns, stated that there was $£ 50,000$ worth of capital lying idle in the town owing to the inadequate railway facilities. Now, if in the case of an industrial town with a population of only $10,000, £ 50,000$ lies dormant owing to the lack of transport facilities, what may be the amount throughout the country ? The early history of railways affords an illustration of the value of transit in the disengaging of capital. The editor of the Times, in an article on railways in the early 'forties, condemned the promotion of railways on the ground that the country was burying capital in earthworks. It proved a great surprise to many to find that as the railway system extended capital was set at liberty, and that the superabundance of capital that showed itself so prominently in the period 1840-1845 was one of the first fruits of the extension of the railway system. The facilities offered by the railway enabled trade to be carried on as demand arose, so that capital was relensed from every description of 
trade and productive industry. The effect of improved transit was that goods were sent in smaller quantities, and the outstanding characteristic of railway merchandise traffic to-clay is the large number of packages of a few hundredweights each. This is a point where the economic interest of the railways and the public is in opposition. The traders want to send their goods in small lots and have quick delivery; on the other hand, the railway would like full truck loads and wellloaded trains. Railway companies have for years endeavoured to get their customers to consign in larger lots, and have offered low rates for consignments in large quantities. If trucks were loacled to their capacity fewer wagons would be required, fewer engines would be necessary to work them, fewer number of staff to deal with them, and so on. Traders are well aware of these rates, but they do not take aclvantage of them, simply because the value of their capital maintained in circulation by sending goods in small lots is greater than the value of the lower cost of carriage when goods are forwarded in larger quantities. Let us take a concrete illustration, which is probably typical of hundreds of business transactions in Lancashire's principal trade. A manufacturer at Blackburn places an order, say, for 50,000 lbs. weight of yarn with an Oldham cotton spinner, delivery to be effected in twenty-five weeks at the rate of 2,000 lbs. weight per week. The value of the order is, say, $£ 5,000$. Under the terms of the contract, the manufacturer will pay the spinner at the rate of $£ 200$ per week. By the time the manufacturer has paid his fourth or fifth weekly account for yarn, say $£ 1,000$, he begins to receive his return from the cloth buyer. This arrangement enables the spinner, manufacturer, and cloth buyer to work with a small capital, as their turnover is quick and the warehouse accommodation is reduced to the minimum. Now the total amount which would be paid to the railway company for the conveyance of yain, week by week, from Oldham to Blackburn, would aggregate to about £15. The manufacturer, therefore, carries the $£ 5,000$ order through with no more than $£ 1,000$ locked up at any time. It is obvious that even free conveyance on the railways would not induce him to deliver the yarn in bulk, because the interest on his capital maintained in circulation, i.e., $£ 4,000$ calculated at 5 per cent for 25 weeks amounts to $\$ 96$. There are many reformers who overlook these fundamental facts. The trader has no interest in low rates and large consignments, because the value of his capital, maintained in circulation by producing goods to order at short notice, is greater than that of low railway rates with his capital locked up in stock. I want to suggest to the textilo trade that if it pays you to conserve capital by sending goods in small quantities, you would be willing to pay a considerably higher rate for the conveyance of goods of the means of trrausit were quick and reliable. This raises a question as to whether a "grand vitesse" sorvice in this country would be successful. There are many instances in this country where dealers send their goods in small lo s by passenger train at onhanced rates rather than by goods train. Some time ago a member of the Leeds Chamber of Commerce recommented the members to make up their goods in parcels of $11 \mathrm{lbs}$. each where possible and send by parcel post at 1s. 2d. per parcel, because the service was prompt and reliable. The available evidence clearly inclicates that rapidity and reliability of railway transit are, together, of greater value to the industrial community than cheap rates. This is quite contrary to the evidence which has been given before Railway Commissions. The witnesses have invariably concentrated their attention on a reduction of railway rates instead of the really vital point of quick and reliable transit.' Cheap rates and unreliable services are expensive when they retard production. History supports this view. The steam locomotive demonstrated its commercial value by raising the rate of movement from four to five times that of any other form of transport, and it soon relegated the canal system to the position of carrying only those goods where quickness of delivery was not essential. Canal rates to-day are, on the whole, cheaper than railway rates, but the traders do not use the canal system extensively. My view is that the canal system will never be resuscitated until the rate of movement of commodities over it is increased.

There are many proposals for railway reform, and, for some years now, public attention has been drawn to that of the New Transport Company. Mr. Alfred Warwick Gattie is the central figure of that movement. He has invented an ingenious electrical device for the quick transfer of goods from waggon to waggon, which he claims would eliminate the delay caused by shunting operations in railway goods yards and marshalling sidings, and thereby raise the rate of movement of traffic. Mr. Gattie is unquestionably right in his contention that quicker transit of goods is desirable, but with his estimates and the practical application of his invention to railway traffic one may join issue. The success of his electrical device depends upon there being a container in which to load the goods, so as to be convenient for handling, and the erection of clearing houses at suitable places where waggons could be concentrated for a redistribution of the containers. The proposed container is a box 12 feet long, 6 feet 6 inches wide, and 7 feet high, and would weigh $19 \mathrm{cwts}$. Its cost is estimated at about £30. Boxes of this kind are in use to-day for special classes of traffic, and flats are provided in connection with Lancashire's staple industry. The value of the container from the point of view of quick movement, is that at the clearing house it would be possible, by means of the electrical appliances, to quickly transfer the containers from truck to truck and thereby eliminate the shunting of waggons which represents a large proportion of the cost of operating goods traffic. At the starting and destination stations it would be possible, by means of cranes, to quickly transfer the container from a motor lorry to a railway truck, or vice-versa.

In a lecture before the Birmingham Chamber of . Commerce, Mr. Gattie claimed that, after paying 5 per cent on the necessary capital of $£ 14,000,000$ for the erection of a clearing house in London, there would be an actual surplus profit of more than 66 per cent per annum. Now, the gross revenue from all the morchandise traffic carried by all railways in the 
United Kingdom in 1913 was $£ 37,400,408$, and only a small proportion of that traffic would require to pass through London. If we were generous and estimated that one-fifth of that traffic would pass through $\theta$ London clearing house, it is difficult to make out how such a huge profit is to be made, unless the New Transport Company charged a very high rate for the use of their appliances. At the present time, the cost of shunting and marshalling of waggons is eunbraced in the railway rate, so that whatever has to be paid for the use of the New Transport Company's appliances will be so much added to the railway charges. If the New Transport Compeny could eliminate the whole cost of shunting on every reilway in Great Britain and Ireland, the sum would not amount to more than $\mathbf{f 4 , 0 0 0 , 0 0 0}$ per annum. In reply to the chairman of the Select Committee on Transport on the 23rd Oet. last, as to what it would cost to equip the United Kingdom with goods clearing housos, Mr. Gattie said it would be roughly $£ 300,000,000$. From the financial point of view, therefore, the cost of establishing clearing houses for goods is out of all proportion to its commercial value.

As to the practical application of Mr. Gattie's contsiner scheme, my view is that it comes within the same category as many inventions designed to eliminate the possibility of failure of the human element, which, unfortunately, is the cause of many railway accidents. When railway safety devices are tested, the railway official has not merely to consider the question whether the device is capable of performing the specific task for which it is designed, but whether it introduces a new set of conditions which have elements of weakness equal to, if not greater than, those existing. with the old arrangements. It is possible, therefore, to have a safety device rejected, although it accomplishes everything the inventor claims, on the ground that a new set of conditions is introduced more dengerous than under the old conditions. The New Transport Company s scheme might eliminate a considerable amount of shunting cost on railways, but it has features calculated to increase both the cost of transport and the cost of opcration. The cost of transport would be increased by reason of the fact that a charge would have to be made in the interests of the New Transport Company for what is now a gr. tuitous serviceshunting. As to the increase in working expenses, a careful record would have to be kept of the movements of all containers to avoid the possibility of their loss. It would be necessary to set up an organisation for their distribution as they were required by traders at various places on the railway. This distribution would be a difficult matter because you might have a truck and no container, or a container and no truck. The cost of maintaining the containers would be 8 considerable item, and it would only slightly, if at all, reduce the cost of maintenance of the railway truck. Cranes would be required to handle the container weighing $19 \mathrm{cwts.}$ and, in a country where small consignments are the outstanding feature of railway merchandise traffic, the dead weight of the container would often be out of all proportion to its load. There is also the question as to whether a container weigh- ing nearly one ton would be acceptable to the traders.

A good deal could be done to raise the rate of movement of transport on railways by a eloser co-operation between reilway administration and traders. The railway administration doos not always appreciate the position of the trader; likewise, the trader does not appreciate the importance, say, of loading up waggons jromptly, and taking delivery of goods immediately they arrive. A few figures will illustrate this point. The average number of loaded trips made per waggon per annum is $90, i$. $^{\circ}$, one evory four days. Suppose the average load of a waggon to be 2 tons, and there are 500,000 tons to move at the rate of one losded trip every four days, 2,777 waggons would be required. If the number of loaded trips per waggon could be raised from one in four to one in three days, only 2.066 waggons would be required-a net gain of 711 waggons. It is obvious that if it pays the trader to have a quick turnover the same principle is sound as regards the use of railway rolling stock. Consultative Councils, consisting of representatives of trade and railways, would be helpful in establishing a better understanding and appreciation of each other's point of view.

The next point I wish to raise is one in which railway shareholders played a large part. On April lst, 1899, an article appeared in the Statist calling attention to the remarkable success achieved by American railways through improved methods of handling. From that time railway reformers have been enthusiastic for the so-called scientific methods of railway operation in America. The central idea of that article was that if the railways in this country would only load waggong up to their capacity, it would mean a less proportion of dead weight to be hauled. If heavior trains were run, fewer engines would be required to haul them: therefore, there would be less coal consumption, and less spent on waggon maintenance, and so on. The Railway Investment Company took the matter up with great keenness. The Company asked for five things:-(1) an increase in the number of waggons behind the engine; (2) increase in the load per waggon; (3) building of engines of greater capacity ; (4) building of waggons of greater capacity : (5) passenger traffic to be handled more efficiently.

Now this theory of the big waggon and heavy freight train assumes that economical haulage is represented by the maximum weight $\mathrm{a}$ locomotive will haul, and it is justified by the misleading statistic "Earnings per goods train mile." This statistic places a premium on slow movement because delay and congestion must arise when waggons are held back waiting for full losds or to make up full train loads equal to the hauling capacity of the locomotive. Undoubtedly, this method increases the average load per waggon, and per train, but it is by no means clear that it is in the long run economical when considered from the point of view of waggon turnover. The longer a waggon is on its journey the greater will be the number required to meet traffic requirements, and the slower the movement the greater is the congestion. We have already seen what effect the speeding up of the user of the waggon would 
have on the number of waggons required. As regards incrensing the load per waggon, and the building of larger waggons, we have seen that the trader's interest lies in the small consignments; therefore, it is useless to build waggons of high-carrying capacity except for special traffics.

The same motive which prompts traders to send goods in small quantities, in order to keep their capital in circulation as long as possible, should be applied to the internal organisation of the railway, for its success depends on keeping engines and rolling stock moving freely over the line. My view is that the Railway Investment Company were ill-advised in pressing for American methods in this country, and that the Chairman of the London and North Western Pailway was right in declering that American methods are, for the most part, inapplicable to the goods traffic of this country.

The policy of loading locomotives up to their weighthauling capacity at low speed as being better than a less heavy loading at higher speeds is open to question. The true test of locomotive service is its ton-mile hauling capacity per hour, which is a combination of weight moved and the speed at which it is moved. Let us take a concrete illustration from the ratings of a firstclass freight locomotive at various speeds on the basis of five hours' actual running time per day.

$\begin{array}{cccc}\text { Speed per } & \text { Miles run } & \text { Maximum } & \text { Ton mileage } \\ \text { hour. } & \text { per day. } & \text { load. } & \text { per day. } \\ 15 & 75 & 1,000 & 75,000 \\ 20 & 100 & 800 & 80,000 \\ 25 & 125 & 600 & 75,000\end{array}$

The locomotive running at 20 miles per hour with 200 tons less weight behind it is able to haul 5,000 more ton miles per day, and is, therefore, 6 per cent more efficient than the $1,000-$ ton train at 15 miles per hour. Now there are probably 3,000 first-class freight locomotives on the railways of this country, and if their ton mile hauling capacity were increased by only 2,000 ton miles per day, their capacity would be increased by $\mathbf{6 , 0 0 0 , 0 0 0}$ ton-miles per day, or $1,878,000,000$ ton-miles per annum. The Coal Con. troller estimated a saving of $750,000,000$ ton-miles per annum as the result of his redistribution scheme, so that the economic loading of locomotives based on their ton-miles hauling capacity is a matter for very serious consideration. Quite apart from the greater efficiency produced by speeding up wherever possible, in order to increase the ton-mile hauling capacity of locomotives, the general features of railway operating economics point to the success of the suggested policy. The amount of traffic which may pass over a fully equipped railway is limited only by the frequency with which trains can safely follow each other; therefore its commercial success depends on keeping the running lines fully occupied and the rolling stock circulating freely. Uniformity of speed and continuous train movement is the ideal to set before the organisation. This principle will be better appreciated if wo mention that to stop needlessly a motor waggon on the roads behind the Front in France during the war meant that the driver would face a court-martial.
One truck halted on a narrow road would delay a moving column of trucks or the movement of big guns.

Our general conclusions in regard to the relationship of railways to national industry are :-

(1) That economy of time in transit means the greater efficiency of our man-power and economy of capital, which have as their corollary the greater productiveness of the country.

(2) That the true test of railway locomotive efficiency is ton-mile hauling capacity per hour.

(3) That the capacity of the railways can be enormously increased by running trains at uniform speeds.

Taking the long view in regard to the future of railways, the short train at frequent intervals, making the fullest use of the line as well as the rolling stock, is the natural stage of evolution to the period of electrification of railways foreshadowed by the interim report of the Coal Conservation Sub-Committee. A policy such as is here outlined is one to be considered entirely from the point of view of national economy. If the increase in the rate of movement were to raise the locomotive running costs of the railways 10 per cent, it would only represent an additional working expense of $£ 1,800,000$ per annum, which, considering the great social and commercial value to be attained, is negligible.

Whether the railway system is controlled by the State or private enterprise, the free movement of passengers and goods within the country must be the standard by which we judge its efficiency. Quick movement is vital to the country's prosperity in order to repair the great wastage of war to conserve our capital resources, and to increase the efficiency of our depleted man-power.

If rapidity of movement can be made one of the greatest assets to an army in war, it is up to us to see that it is made one of the greatest assets to our commercial and industrial army in peace time.

\section{Discussion.}

Col. F. R. McConnel (Manchester) said he now realised that in regard to the adoption of containers there were two sides to the question. The L. \& Y. Company had seen great advantage in the use of flats, which could be loaded up without delaying the truck. A similar kind of economy was possible in the use of the trailer in connection with motor vehicles. In the handling of goods, he feared that a good deal of delay was caused by the inadequacy of modern appliances, at many places, for the loading and unloading.

Mr. H. P. Greg (Stockport) said the use of flats was advantageous, but he thought it might be possible to use smaller flats, which could be readily picked up by the cart at the warehouse. Time would be saved on every hand. The matter was one for experiment. There was a great deal of traffic in goods which it was desirable should be placed in covered waggons. There appeared to be some difficulty in loading these waggons, and he suggested a movable top so as to admit of overhead loading instead of loading from the side. In the unloading of coal, too, he thought considerable 
improvement in method might be effected. At a great many of the stations the introduction of a few laboursqving devices might be well worth consideration.

Mr. John Crompton (Manchester) favoured quick transport even at a higher cost, but he should expect the rate to be subject to rebate if there was failure of performance in point of time occupied. On many railways the means of handling goods at local stations ought to be improved. Coal was often handled in a wasteful manner.

The author of the paper, in reply, said the railway companies had learnt a good deal in the last two or three years from the point of view of co-operative working. There was still room for eloser co-operation between industry and railways. With regard to the use of containers, if the trader detained the container the railway would be in the same position as with the detention of waggons. Certainty of delivery was the ideal to be striven for. The railways could not hope to satisfy everybody, but their services should be distributed equally. The vogue of small consignments, he believed, had come to stay. The question of providing labour-saving appliances, particularly in regard to the handling of coal traffic at ports and large depots, was under consideration.

Meeting at Bolton, 18th February, 1919.

Mr. William Hears in the Chair. PRIVATE POWER PLANTS VERSUS PUBLIC SUPPLY. By G. B. WILLIAMSON.

Thн Textile Institute cannot be accused of neglecting the very important question of power supply. A prominent place has been given to it in several sessions, and the data presented to the meetings at Hawick in 1912, at which there was very full discussion of the various alternative methods of mill driving, is still a most interesting field of reference. For some time, such matters were the special concern of a " Mill Driving Committee," but the war suspended this amongst other good things. In view of the increasing importance of the question of power, particularly from the point of view of fuel conservation. it would be well if such a body were resuscitated.

On all hands it is admitted that the need for thoroughly impartial investigation into possible economies in the generation and use of power is now most urgent, and, in spite of all the attention which has been given to mill driving, particularly during the past ten years, it is still a fact that doctors differ, and that our cotton mills present a confusion of systems which is deplorable. Not only are there rival methods, but what appears very much like fickleness in the changes which have been made during recent years. Mills formerly rope driven have been converted to turboelectric, and turbo-electric mills have been converted to rope driving. Private plants have been dismantled and the public electricity supply connected, and others who had such a supply for years have now put down their own generating plant. Such differences in treatment are not to be accounted for by circumstances of site or internal arrangement, but appear to be due, in some instances at least, to failure to bear out the promise of earlier efforts, and to that degree are a challenge to the original contractor. In vew of the recommendations of the several Government committees who have had power questions under considera. tion, the history and record of electric driving in mills is particularly disconcerting.

According to two very important committees of experts, there is only, in the light of present knowledge. one way of wisdom. Along that way we are to scrap or gradually discontinue the present conflicting system, under which there are many thousands of privatelyowned power plants, and of all types, and to establish a national system of power generation, with electrical transmission from some sixteen so-called super-power stations, the capacity of each being not less than 150,000 horse power, and conveniently placed with regard to fuel and water supply. When we read that the saving of fuel to be effected by such a change is not less than 55 million tons per annum, and the saving in all direct and indirect ways not less than 100 millions per annum in money, we are given somewhat furiously to think. The textile trades stand third in order of horse power and fuel consumption, and it is our duty, in face of figures such as these, to inquire how far we are to blame for such enormous waste, and to what degree we can help to eliminate it by alterations more or less revolutionary in our power plants.

I do not think the general conclusion of the Coal Conservation Sub-Committee that the fuel consumption of the plants of the United Kingdom is not less than 5 lbs. per H.P. hour, can be applied with any truth to the textile industry, and particularly to the cotton trade. The assumption in Appendix A of the report, that the reported horse power of engines is in use for only 1,095 hours per annum, is based upon conditions which do not apply to power plants in general, and whilst there may be some uncertainty as to the actual horse-power developed, I would suggest 2,500 hours as more nearly the actual full-load running time. With this modification, and after allowing 30 per cent deduction for coal used for purposes other than power, which, as dye and bleach works, finishing mills, ete., are included, I suggest is nearer the mark than the committee's general figure of 25 per cent, the coal per I.H.P. hour appears to be about $3.3 \mathrm{lbs}$. in 1907 (this being the year taken for Census of Production). From a fairly extensive knowledge of the conditions prevailing in the textile industry, I would suggest that the actual consumption to-day is just below 3 lbs., and $I$ am inclined to place it very near to $\mathbf{2 \cdot 8}$, which, but for the postponement of alterations and replacements during the last four years, would have been, at most, $2 \cdot 6$ lbs. The greater portion of textile mill power is in the large spinning mills of round about 80,000 spindles, and in these it is very rare to find a consumption of more than $2.25 \mathrm{lbs}$, and not at all uncommon, with fuel equal to pre-war quality, to find records of below 2 , even down to 1.5 in cases where one full load indication per week is used for calcula. tion. The standard boiler pressure is now $160 \mathrm{lbs}$., with moderate superheat, and any good engine, not seriously overloaded, can be set to run on a steam consumption of $12 \mathrm{lbs}$. per I.H.P. hour under these 